\title{
The effect of plant-soil treatment plant on the groundwater quality
}

\author{
Katarzyna Pawęska ${ }^{1, *}$ \\ ${ }^{1}$ Wrocław University of Environmental and Life Sciences, Institute of Environmental Engineering, \\ pl. Grunwaldzki 24, 50-363 Wrocław, Poland
}

\begin{abstract}
The paper presents the impact assessment of the plant-soil treatment plant on the groundwater quality. The physicochemical composition of groundwater was analysed. The samples were collected form the piezometer network located in the irrigated area and around it. Water quality tests were carried out in 2014 with the frequency of the month. Changes in the physicochemical composition of groundwater were determined with reference to quality of domestic wastewater used for irrigation. The obtained results were also referred to groundwater parameters limits before the facility's operation started. As a result of many years of exploitation the groundwater quality under the irrigated area has changed. The boundary of individual segments of wastewater treatment plant is clearly marked by the change in concentrations of the observed pollution indicators. The highest values of organic matter expressed by BOD and COD were observed in the groundwater the I segment (respectively $6.9 \mathrm{gO}_{2} \cdot \mathrm{m}^{-3}$ and $66.2 \mathrm{gO}_{2} \cdot \mathrm{m}^{-3}$ ). This was the results of a change in the irrigation regime. As the result of irrigation, an increase of nitrate (V) and nitrate (III) was also observed in comparison to their preoperational values. Plant-soil treatment plant prove high effectiveness of work. However, due to their significant impact on the groundwater quality their operating should be gradually reduced.
\end{abstract}

\section{Introduction}

Inextricably linked to the uptake and use of water, the problem of wastewater formation is connected and it disposal is still an important issue. This is mainly visible in developing countries, where approx. $80 \%$ of generated wastewater is discharged into the environment untreated [1]. One of the wastewater disposal method along with the use of their potential is agricultural use, which creates both benefits and threats. The fertilizing potential of wastewater is very often use in agriculture. It use this potential to supplement the irrigation, which is part of, among others the sustainable use of water resource [2]. This method of wastewater management is widespread mainly in countries with significant water deficit [21]. Based on experiences from agricultural wastewater use facilities, wastewater treatment plants that combine intensive biomass production using physicochemical properties of wastewater have been created $[10,22]$. The fertilizer potential of wastewater

\footnotetext{
*Corresponding author: katarzyna.paweska@upwr.edu.pl
} 
is confirmed by many researchers, both in Europe and around the World [3-5]. Except the domestic and industrial sewage [6], rainwater is also used for irrigation as well as gray wastewater [3, 7-9].

Depending on the place where the wastewater is formed, their composition may significantly differ, however this does not diminishing their potential, it only means that preparing them for re-use becomes both time-consuming and expensive. Unfortunately, no other source of water as easily accessible as wastewater has been found so far. This is undoubtedly the advantage of using wastewater to intensify plant production, in addition this source is characterized by the possibility of a constant supply regardless of the season. Despite many advantages associated with agricultural wastewater use, this way of it managing is related to the risk resulting from the lack of control over the quality of the wastewater used for irrigation and quality of leachate introduced into the receivers e.g. lakes, rivers, see. For this purpose, both standards, regulations and guidelines for good practise are prepared to minimize the risks associated with the re-use of wastewater, which is just as important as the proper management of irrigated wastewater.

Re-use of water and the components contained in the wastewater (especially multiannual irrigation) significantly affect the physical properties of the soil as well as quality of groundwater under irrigated area. This view is confirmed by research of many scientists [10-16], which prove the variably impact of long-term wastewater use on the environment.

Wastewater irrigation provides the introduction into the soil mainly nutrients such as nitrogen, phosphorus and organic matter, which are easy available for plants.

Not only the physical properties of soil are changing but also texture, structure, porosity with reference to the load of suspension introduced with wastewater. Hydraulic conductivity changes and indirectly filtration coefficient changes are also caused as the result of multiannual wastewater irrigation. Researchers also noted the effect of wastewater irrigation on increasing soil erosion [17]. The most significant changes occurring in the light soils [18]. Wastewater is the source of various components introduced into soil profile such as macro and micronutrients. However, assuming such a method of wastewater utilization, it is necessary to take into consideration the component balance between various environmental elements; soil, groundwater and plant species.

The main aim of the work was the assess the impact of plant-soil treatment plant on the groundwater quality in relation to wastewater irrigation. Research were conducted for a one year period on the object adapted to the wastewater treatment in soil.

The impact of the wastewater operating was determined by assessing changes of selected pollution indexes in compare to groundwater physicochemical composition before full operation starting. The analyse was carried out using the deterministic spatial interpolation method (IDW - Inverse Distance Weighting).

\section{The research object characteristic}

The conducted research concerned the object located in Brzezno village (commune Prusice, Dolnośląskie province), designed for yearly collection of domestic wastewater. The plant-soil treatment plant was put into operation in 1997 [20], and was dedicated to wastewater treatment produced by 350 inhabitants (it has been used up to now). Treatment processes based on closing the circulation matter through the soil. The two-stage wastewater treatment plant consist on accumulating tank with capacity $110 \mathrm{~m}^{3}$ and biological part (including 21 plots of 0.11 ha area each, divided into 4 segments). Wastewater after preliminary (mechanical) treatment in septic tanks (located in the village) is collected in accumulating tank, and then through supplying ditch is introduce into selected plot (fig. 1). 


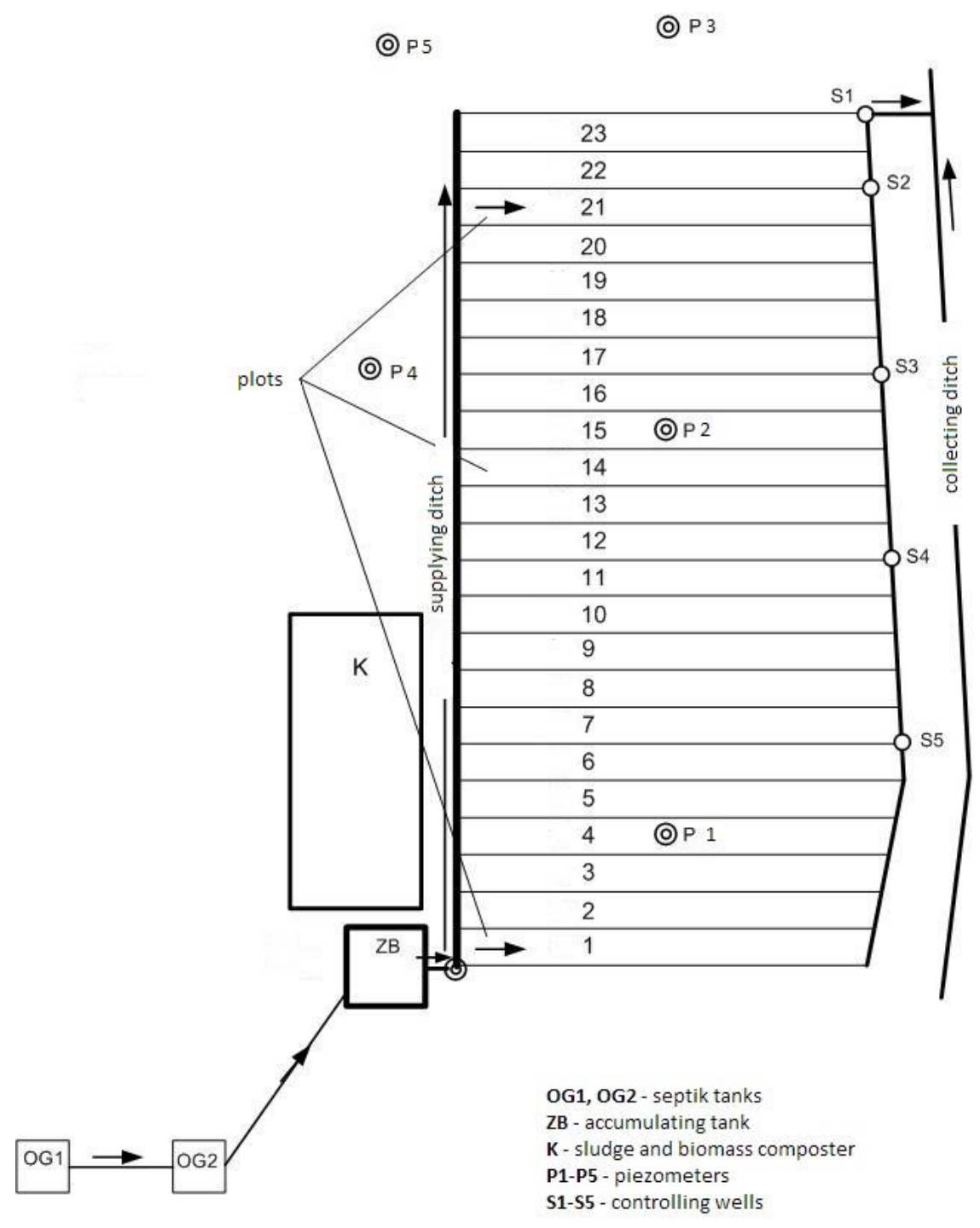

Fig. 1 Scheme of plant-soil treatment plant.

The irrigation dose resulting from ground-water condition is $97 \mathrm{~mm}$ [20]. Wastewater after entering the plot is percolated into the plot surface. There are poplars planting and grass mixture used on the irrigation area. Water and components contained in wastewater are accumulated by plants. Part of wastewater infiltrates into the soil and is treated in soil profile. About $1 \mathrm{~m}$ below the ground, in the dikes of each plot a drainage pipe is installed to capture the treated wastewater and discharge it to the receiver. In order to control changes in groundwater quality a piezometers net on plant-soil treatment plant area was installed ( 2 piezometer in irrigated area, 3 piezometers outside irrigated area).

Research were conducted in 2014 with one month frequency. Samples from accumulating tank (wastewater entered into plots) and from 5 piezometers (groundwater) were collected. In each samples basis parameters such a BOD, COD, total suspension, total 
residue, electrolytic conductivity, $\mathrm{pH}$, nitrogen forms (total nitrogen, ammonium nitrogen, nitrate (V), nitrate (III)) were measured, according to standards [19]. Analyses in Faculty Laboratory of Water and Wastewater of Wrocław University of Environmental and Life Sciences were performed. Directly, during sampling, the groundwater level was measured. Statistically analysed were conducted with software package Statistica version 13.0 (Statsoft 2015) as well as deterministic spatial interpolation method (IDW - Inverse Distance Weighting) was applied [24, 25]. Spatial interpolation was performed using the ArcGIS Spatial Analyst. The spatial distribution of the selected parameters of groundwater quality was created in GRID $1 \mathrm{~m}$ model. For vector layer (represented plots of wastewater treatment plant) average values from spatial distribution models of the analysed parameters were assigned using zonal statistic function.

\section{Ressults and discusion}

Wastewater introduced on the wastewater treatment plant area was preliminary treated in multi-chambers settling tanks located in the Brzeźno village. In the next step, through supplying ditch and valves, wastewater flowed to selected plot. During research period, $14482 \mathrm{~m}^{3}$ wastewater was delivered to the wastewater treatment plant area, $8938 \mathrm{~m}^{3}$ with slurry tanker fleet.

In table 1 basic physicochemical parameters of domestic wastewater introduced into wastewater treatment plant area were summarized.

Table 1. The physicochemical composition of wastewater introduced on the wastewater treatment plant area.

\begin{tabular}{|c|c|c|c|c|c|}
\hline \multirow{2}{*}{ Pollution indexes } & \multirow{2}{*}{ Unit } & \multicolumn{4}{|c|}{ Values of pollution } \\
\cline { 3 - 6 } & & Mean & Min. & Max. & St.Dev. \\
\hline BOD & $\mathrm{gO}_{2} \cdot \mathrm{m}^{-3}$ & 209.04 & 105.50 & 318.00 & 56.03 \\
\hline COD & $\mathrm{gO}_{2} \cdot \mathrm{m}^{-3}$ & 631.30 & 345.80 & 1043.70 & 250.62 \\
\hline Total suspension & $\mathrm{g} \cdot \mathrm{m}^{-3}$ & 257.50 & 80.00 & 535.00 & 145.23 \\
\hline $\mathrm{pH}$ & - & 7.40 & 7.20 & 8.10 & 0.27 \\
\hline $\begin{array}{c}\text { Electrolytic } \\
\text { conductivity }\end{array}$ & $\mu \mathrm{S} \cdot \mathrm{m}^{-1}$ & 1765.60 & 1295.00 & 2790.00 & 369.60 \\
\hline Total residue & $\mathrm{g} \cdot \mathrm{m}^{-3}$ & 1121.40 & 115.00 & 1820.00 & 392.98 \\
\hline Total nitrogen & $\mathrm{gN} \cdot \mathrm{m}^{-3}$ & 116.50 & 67.95 & 195.95 & 33.53 \\
\hline Ammonium nitrogen & $\mathrm{gN}-N H_{4} \cdot \mathrm{m}^{-3}$ & 101.10 & 60.20 & 189.46 & 39.42 \\
\hline Nitrate nitrogen (V) & $\mathrm{gN}-N O_{3} \cdot \mathrm{m}^{-3}$ & 0.60 & 0.00 & 4.31 & 1.08 \\
\hline Nitrate nitrogen (III) & $\mathrm{gN}-N O_{2} \cdot \mathrm{m}^{-3}$ & 0.044 & 0.00 & 0.12 & 0.04 \\
\hline BOD/COD & - & 0.37 & 0.16 & 0.55 & 0.13 \\
\hline BOD/N & - & 1.92 & 0.92 & 3.68 & 0.74 \\
\hline
\end{tabular}

The composition of wastewater supplied into biological stage of plant-soil treatment plant was similar to the physicochemical composition of wastewater generated in non-urban areas [23]. Partial sewerage system influenced on the content of fresh organic matter, which is important by introducing wastewater into soil. The organic matter as well as nutrient content in wastewater used for irrigation should indicate their ability to biological decomposition. Such dependence in indicated by BOD/COD ratio (tab. 1), which in the analysed case was 0.37 . However, the ratio of organic matter (BOD) and total nitrogen indicates the favourable conditions for the nitrification process.

Based on the spatial analysis of data, using the IDW model, the distribution of selected parameters under the irrigated area was developed. The groundwater level under irrigated area varied between 0.31 to $0.93 \mathrm{~m}$. The deepest groundwater level was noticed for plots of segment I (plots 1-6), then in segments II-IV the increase of groundwater level until plot 
no. 21 was observed. For this plot the shallowest level of groundwater was measured $(0.34 \mathrm{~m})$. Such changes in groundwater level could be reflected in the long-term irrigation regime which is also visible in concentrations changes of total suspension, dry residue and electrolytic conductivity. The total suspension content measured in groundwater is result of long-term wastewater treatment plant operating. Segment I (successive overloaded) [20] was characterized by highest values of this parameter $\left(99.58 \mathrm{~g} \cdot \mathrm{m}^{-3}\right)$.

Analogous concertation's changes in case of dry residue and electrolytic conductivity was observed. Extreme values occurred for plot no. $31222.11 \mathrm{~g} \cdot \mathrm{m}^{-3}$ and $1742.4 \mu \mathrm{S} \cdot \mathrm{m}^{-3}$ (dry residue and electrolytic conductivity) respectively (fig. 2). Steady overloading of segment I caused clogging of plot's surface, extending of wastewater infiltration time and then redirecting irrigating to next segments. The change of organic matter contents expressed by BOD and COD in groundwater were similar. Groundwater in segment I was characterized by lowest values of BOD and COD, for plot no. $32.8 \mathrm{gO}_{2} \mathrm{~m}^{-3}$ and $36.03 \mathrm{gO}_{2}$ $\mathrm{m}^{-3}$ respectively. For plots of next segments, constant increase in organic matter till to maximum value, which estimated for plot no. 21 (segment IV) was noticed. The highest measured values for this plot were $6.9 \mathrm{gO}_{2} \cdot \mathrm{m}^{-3}$ for BOD and $66.2 \mathrm{gO}_{2} \cdot \mathrm{m}^{-3}$ for COD. The content of total nitrogen in groundwater samplings is depend on sum of ammonium nitrogen and nitrates (V) and (III). Changes in total nitrogen concentrations during research period were the result of pollution load decrease of the firs wastewater treatment plant's plots (fig. 2). Therefore, the lowest concentration of this parameter in groundwater sampling of plots 1-5 was observed as well as steady concentration increase in the next segments. The similar characteristic of concentration's changes for ammonium nitrogen ions can be observed, with a small decrease of concertation for segment's III plots and then a steady concertation increase up to the last plot. In the case of nitrate (V) and (III) concertation changes for analyzed period, the highest values for plots of segments III and IV were estimated (fig. 2). The narrowest changes range was noticed for $\mathrm{pH}$. Measured values were in the range 7.1-7.3 with downward trend for next plots of wastewater treatment plant.

Comparing the average groundwater physicochemical composition before and after 17 years of continued operation, the clear impact of wastewater irrigation on the groundwater quality can be noticed (tab. 2). The concentration of nitrate (V) ions in the analyzed groundwater samples increased 13 times. The similar increase was also observed in term of organic matter, which indicates that the soil profile is losing the ability to reduce of the pollution load.

Table 2. The physicochemical composition of groundwater before operation (1994) and after long-term irrigation (2014).

\begin{tabular}{|c|c|c|c|c|c|}
\hline \multirow{2}{*}{ Parameter } & \multirow{2}{*}{ Unit } & \multicolumn{3}{|c|}{1996} & \multirow{2}{*}{2014} \\
\hline & & $\mathrm{P} 2$ & P3 & $\mathrm{P} 4$ & \\
\hline $\mathrm{pH}$ & - & 7.3 & 6.7 & 7.1 & 7.2 \\
\hline Electrolytic conductivity & $\mu \mathrm{S} \cdot \mathrm{m}^{-1}$ & - & - & - & 1364.2 \\
\hline Total nitrogen & $\mathrm{gN} \cdot \mathrm{m}^{-3}$ & - & - & - & 17.7 \\
\hline Ammonium nitrogen & $\mathrm{gN}-\mathrm{NH}_{4} \cdot \mathrm{m}^{-3}$ & 0.4 & 0.32 & 0.32 & 2.95 \\
\hline Nitrate nitrogen $(\mathrm{V})$ & $\mathrm{gN} \mathrm{NO}_{3} \cdot \mathrm{m}^{-3}$ & 0.82 & 1.34 & 0.38 & 10.61 \\
\hline Nitrate nitrogen (III) & $\mathrm{gN}-\mathrm{NO}_{2} \cdot \mathrm{m}^{-3}$ & 0.043 & 0.054 & 0.022 & 0.077 \\
\hline COD & $\mathrm{gO}_{2} \cdot \mathrm{m}^{-3}$ & 4.3 & 4.2 & 3.8 & 52.65 \\
\hline BOD & $\mathrm{gO}_{2} \cdot \mathrm{m}^{-3}$ & - & - & - & 5.05 \\
\hline Dry residual & $\mathrm{g} \cdot \mathrm{m}^{-3}$ & 694 & 394 & 893 & 1034.4 \\
\hline Total suspension & $\mathrm{g} \cdot \mathrm{m}^{-3}$ & - & - & - & 89.4 \\
\hline Groundwater level & $\mathrm{m}$ & 0.82 & 0.67 & 0.61 & 0.64 \\
\hline
\end{tabular}



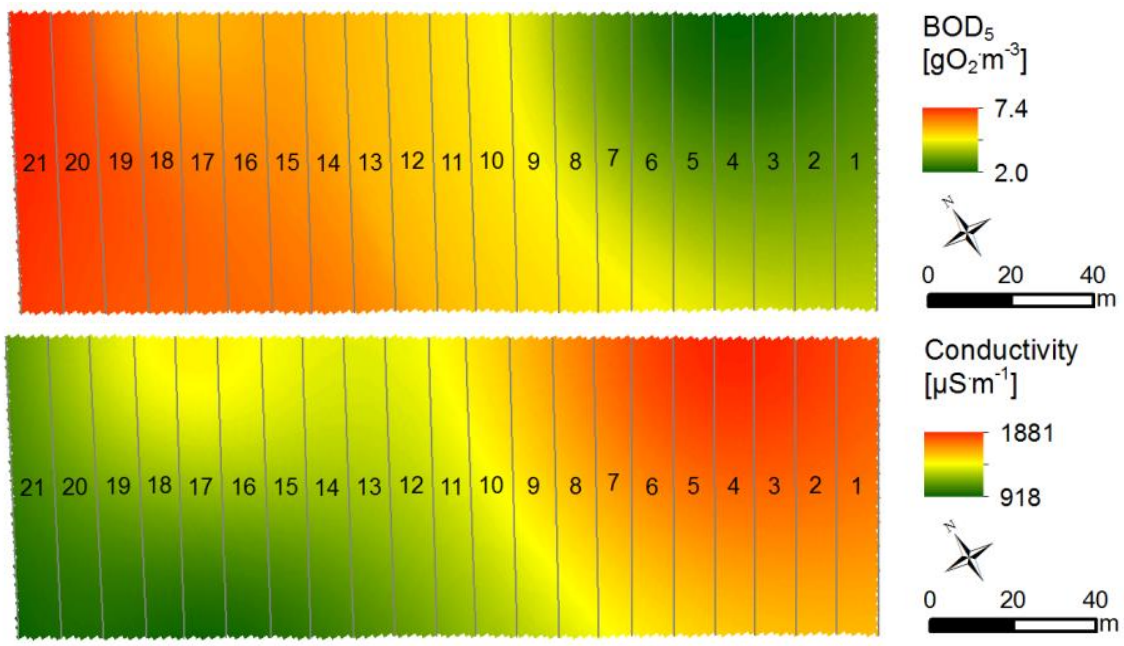

\section{Conductivity} $\left[\mu \mathrm{S} \mathrm{m}^{-1}\right]$
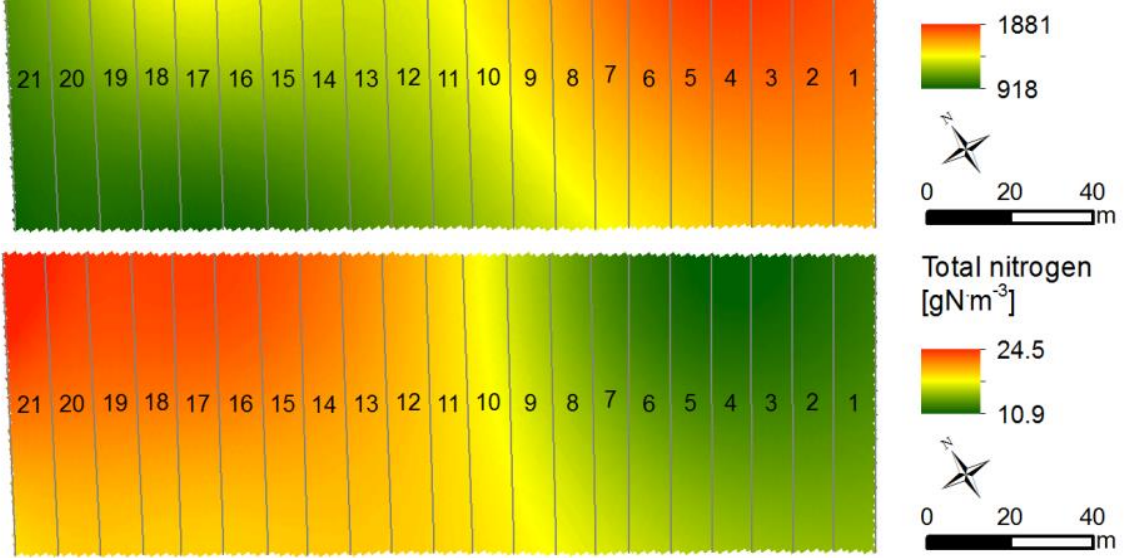

Total nitrogen $\left[\mathrm{gNm}^{-3}\right]$
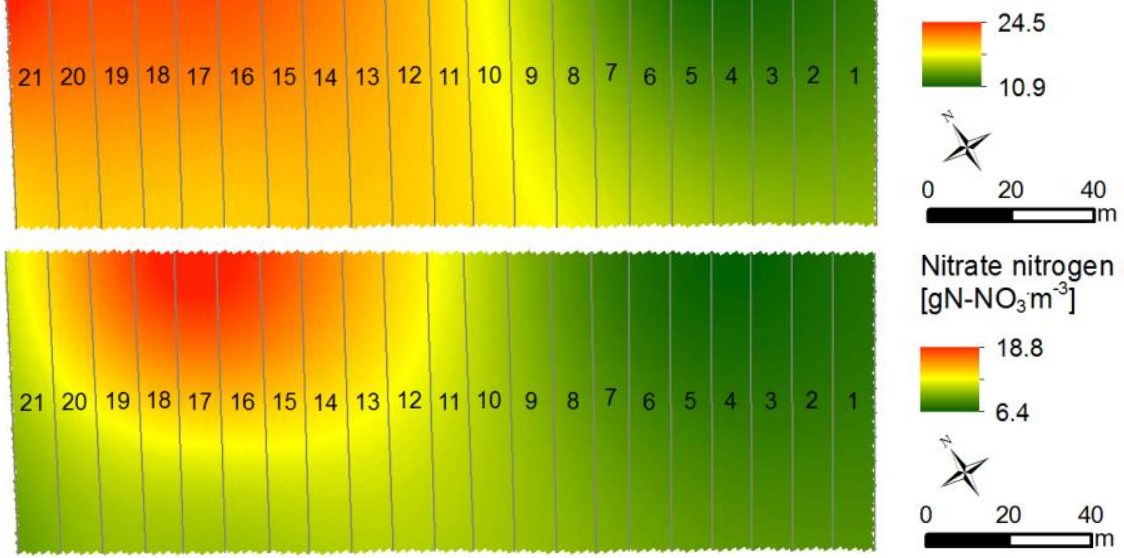

Nitrate nitrogen (V) $\left[\mathrm{gN}-\mathrm{NO}_{3} \mathrm{~m}^{-3}\right]$
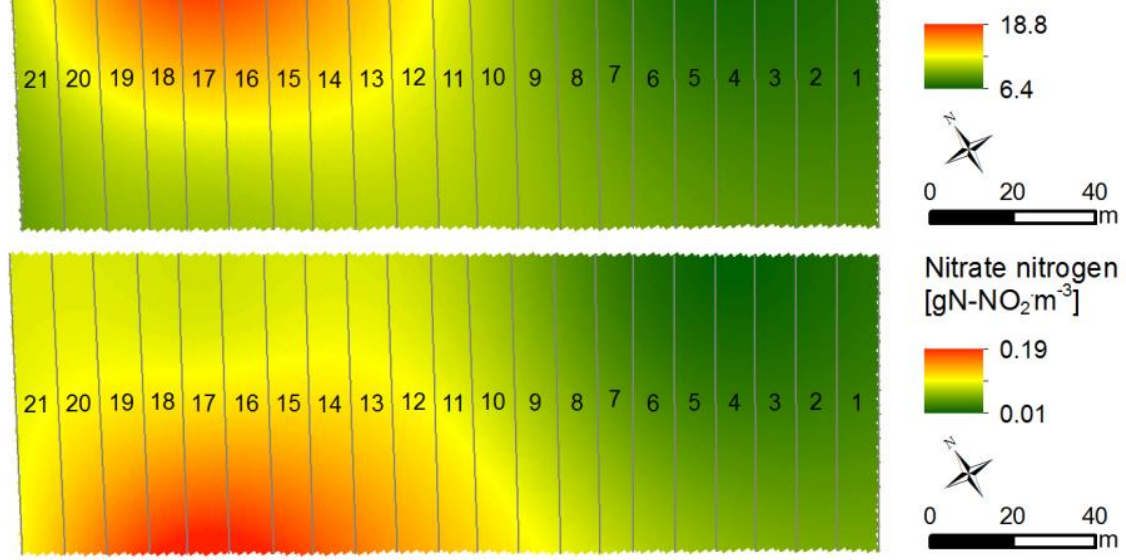

Nitrate nitrogen (III) $\left[\mathrm{gN}-\mathrm{NO}_{2} \mathrm{~m}^{-3}\right]$
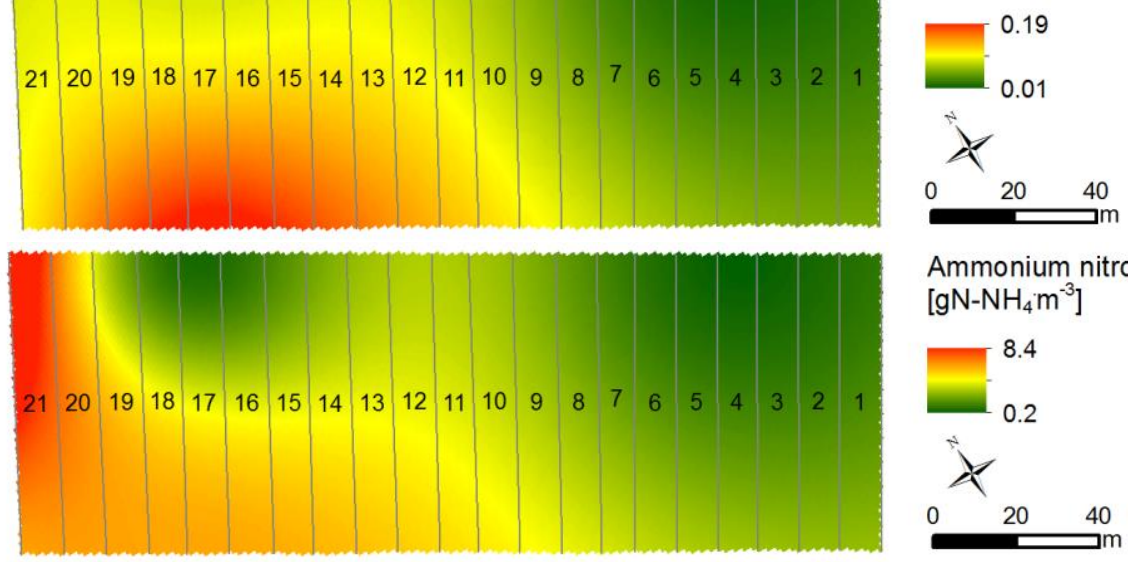

Ammonium nitrogen $\left[\mathrm{gN}-\mathrm{NH}_{4} \mathrm{~m}^{-3}\right.$ ]

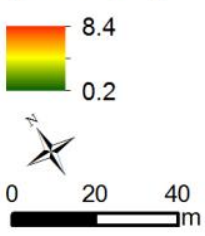

Fig. 2 Spatial distribution of selected pollutant parameters in groundwater under irrigated area of plant-soil wastewater treatment plant. 


\section{Conclusions}

Based on research and observations follwin conclusions were formed:

1. Wastewater long-term irrigation had negative impact on the groundwater quality.

2. During the irrigation, surface of plant-soil treatment plant was not regular loaded of pollution load, which caused gradual saturation of soil profile plots with organic matter and significant increase of the nitrate ions $(\mathrm{V})$ concentrations.

3. Plant-soil treatment plant after long-term irrigation regime should be re-evaluated in terms of quality groundwater changes and then eventually excluded from use in case of pollution indicator concentrations exceedance.

\section{References}

1. M.A. Mojid, G.C.L. Wyseure, S.K. Biswas, J. Soil Sci. Plant Nutr. 12(4), 655-665 (2012)

2. S. Toze, Desal. 187, 41-51 (2006)

3. T.Asano, M.Maeda, M.Takaki, Wat.Scien.Techn. 34(11), 219-226 (1996)

4. J. Haarhoff, B.Van der Merwe, Wat.Scien.Techn. 33(10-11), 25-35 (1996)

5. M.M.Shereif, M. El-S.Easa, M.I.El-Samra, K.H.Mancy, Wat.Scien.Techn. 32(11) 137-144 (1995)

6. P. Guillaume, D. Xanthoulis, Wat.Scien.Techn. 33(10-11), 317-326 (1996)

7. W. Leal Filho (ed.), Climate Change and the Sustainable Use of Water Resources, Climate Change Management, (Springer-Verlag, 2012)

8. A. J. Clemmens, R. G. Allen, and C. M. Burt, Water Resour.Res. 44(W00E03),1-16 (2008)

9. J. M.Anderson, Wat.Scien.Techn. 33(10-11), 37-43, (1996)

10. J. Boćko, Roczniki Gleboznawcze 31(3/4), 149-154, (1980)

11. C. Chakrabatri, Env.Intern. 21(3), 333-339 (1995)

12. F. Czyżyk, Wpływ wieloletnich nawodnień ściekami na glebę, wody gruntowe i rośliny (IMUZ, 1994)

13. K. Konecka-Betley, F. Białkiewicz, D. Czępińska-Kamońska, E. Janowska, Roczniki Gleboznawcze 31(2), 151-173 (1980)

14. W. Schnaak, Th. Kuchler, M. Kujawa, K.-P. Henschel, D. Sussenbach, R. Donau, Chemosphere 35(1/2), 5-11 (1997)

15. S. Uziak, Z. Klimowicz, E. Lewandowska, J. Melkej, K. Steinbrich, Roczniki Gleboznawcze 31(1), 3-26 (1980)

16. R. Yadav, B. Goyal, R.K.Sharma, S.K.Dubey, P.S. Minhas, Env.Intern. 28, 481-486 (2002)

17. J. Tarchitzky, Y. Golobati, Y. Chen, R. Keren, Soil Sci.Soc.AM.J. 63(3), 554-560 (1997)

18. M. Licznar, J. Drozd, S.E. Licznar, J. Weber, J. Bekier, K. Walenczak, J. Szadorski, E. Pora, Woda-Środowisko-Obszary wiejskie, 10, (3/31), 129-137 (2010)

19. Rozporządzenie Ministra Środowiska z dnia 18 litopada 2014 r. w sprawie warunków jakie należy spełnić przy wprowadzaniu ścieków do wód lub do ziemi,oraz w sprawie substancji szczególnie szkodliwych dla środowiska wodnego, Dz.U 2014 poz.1800

20. K. Pawęska, K. Kuczewski, Skuteczność oczyszczania ścieków bytowych w oczyszczalniach roślinno-glebowych o różnej eksploatacji, (Monografie LX, UP we Wrocławiu, 2008)

21. V.P Singh, B. Maheshwari, B. Thoradeniya, Options and Strategies for Balanced Development for Liveable Cities: An Epilogue. In: Maheshwari B., Singh V., 
Thoradeniya B. (eds) Balanced Urban Development: Options and Strategies for Liveable Cities. Water Science and Technology Library, 72, Springer, Cham (2016)

22. J. Kutera, Wykorzystanie ścieków w rolnictwie (PWRiL, 1988)

23. L. Lijó , S. Malamis, S. González-García, F. Fatone, M.-T. Moreira, E. Katsou, Water Res. 109(1), 173-185 (2017)

24. Y. Chen, X. Jiang, Y. Wang, D. Zhuang, Process Saf. Environ. Prot. 113, 204-219 (2018)

25. R. Mirzaei, M. Sakizadeh, Environ Sci Pollut Res 23, 2758-2769 (2016) 